\title{
Subunit Vaccine Approaches for African Swine Fever Virus
}

\author{
Natasha N. Gaudreault * and Juergen A. Richt * \\ Department of Diagnostic Medicine \& Pathobiology, College of Veterinary Medicine, Kansas State University, \\ K224 Mosier Hall, 1800 Denison Ave, Manhattan, KS 66506, USA \\ * Correspondence: nng5757@vet.k-state.edu (N.N.G); jricht@vet.k-state.edu or jricht@ksu.edu (J.A.R.); \\ Tel.: +1-785-532-2793 (J.A.R.)
}

Received: 19 May 2019; Accepted: 21 June 2019; Published: 25 June 2019

\begin{abstract}
African swine fever virus (ASFV) is the cause of a highly fatal disease in swine, for which there is no available vaccine. The disease is highly contagious and poses a serious threat to the swine industry worldwide. Since its introduction to the Caucasus region in 2007, a highly virulent, genotype II strain of ASFV has continued to circulate and spread into Eastern Europe and Russia, and most recently into Western Europe, China, and various countries of Southeast Asia. This review summarizes various ASFV vaccine strategies that have been investigated, with focus on antigen-, DNA-, and virus vector-based vaccines. Known ASFV antigens and the determinants of protection against ASFV versus immunopathological enhancement of infection and disease are also discussed.
\end{abstract}

Keywords: African swine fever virus; ASFV; vaccines; subunit vaccines; antigens; immunogens; protective immunity; disease enhancement; antibody dependent enhancement

\section{Introduction}

African swine fever virus (ASFV) causes a devastating and economically significant disease of both domestic and wild swine (Sus scrofa). There is no available vaccine for ASFV, and current control methods involve quarantine and culling of animals in affected areas and regions. ASFV is found in Africa, where it is maintained in a sylvatic cycle between soft ticks, warthogs, and bushpigs which do not develop disease with ASFV infection [1]. On the other hand, ASFV can cause high morbidity and mortality in domestic pigs and wild boar [2,3].

ASFV is endemic in Africa, where it was first described in the early 1900s [4,5]. In 1957, ASFV emerged outside of Africa in Portugal and from 1960 to the 1980s subsequently spread across Western Europe. In the 1970s to early 1980s, ASFV emerged in the Caribbean islands and Brazil. By the mid-1990s, ASFV had been eradicated in the Americas and Europe, with the exception of Sardinia, which has remained endemic since 1982 [4,5]. In 2007, ASFV was introduced to the Caucasus region and quickly spread into the Russian Federation and Eastern Europe, where it has continued to circulate [4-8]. More recently, ASFV has been found as far west as Belgium in wild boar [9]. Currently, ASFV is circulating in domestic swine of China and has spread to surrounding countries, including Mongolia, Vietnam, Cambodia, Laos and North Korea (DPRK) [10,11]. There are currently 24 genotypes of ASFV based on the major capsid protein p72, and 8 serotypes based on the viral hemagglutinin CD2-like protein (CD2v) and C-type lectin [12-15]. The virus circulating in Europe, Russia, and China has been identified as a highly virulent, genotype II strain [16-19]. ASFV is highly contagious and stable in the environment and can be readily transmitted through infected pork products and contaminated fomites [20-24]. Thus, ASFV poses a significant threat to the swine industry worldwide, and the need for an ASFV vaccine is of high priority. 
The pursuit for an effective vaccine against ASFV has been largely unsuccessful. This is due to the complexity of the virus and our limited understanding of ASFV virulence factors and the correlates of protection. ASFV, the sole member of the family Asfarviridae, has a large double-stranded DNA genome ranging in size from 170 to $190+\mathrm{kb}$ depending on the strain, and encodes more than 150 proteins, many of which remain uncharacterized [25-28]. Up to 68 structural proteins have been identified from the virion alone [29]. Identified ASFV antigens and immunogens, and ASFV targets investigated for vaccine development are discussed later in this review.

\section{Inactivated and Live Attenuated ASFV Vaccines}

Conventional vaccine approaches such as inactivated virus have proven to be ineffective [30,31]. More success has been seen with naturally attenuated isolates [32,33] or modified live viruses [33-39]. However, protection is generally only against homologous strains of the same genotype, and not heterologous virus challenge. Furthermore, live attenuated strains often have associated adverse side-effects, such as skin lesions and joint swelling, which have hindered their development as vaccines [32,40-43]. Live virus vaccines can also cause chronic or persistent infections and have the potential to revert to virulence. Another issue with live attenuated vaccines is the lack of a stable cell line for production, since ASFV preferentially replicates in primary monocyte/macrophage cells. For these reasons, subunit and vectored ASFV vaccines have been explored as an alternative viable option.

\section{Subunit, DNA, and Virus-Vectored ASFV Vaccines}

Several subunit, DNA, and virus vector vaccine strategies have been investigated with limited success and sometimes inconsistent results. This inconsistency could be attributed to a variety of factors, including the type of vaccine, vaccination strategy, the antigens used, and the immune response induced, as well as the challenge model used, including factors like animal genetics, virus strain, and vaccine and challenge dose. Antigen- and DNA-based vaccines provide a targeted approach with fewer side-effects and increased safety compared to live or inactivated virus vaccines. A number of immunogenic ASFV proteins have been identified and investigated for a role in protection against ASF, which are summarized and discussed later in this review. ASFV structural proteins p30, p54, p72, pp62, and CD2v encoded by genes CP204L, E183L, B646L, CP530R, and EP402R, respectively, have been the main targets of subunit and DNA vaccine strategies, including vaccination with either individual ASFV antigen targets or as multitarget cocktails. The following subsections summarize the subunit, DNA, and virus-vectored ASFV vaccines evaluated thus far.

\subsection{Antigen-Based Vaccines}

Earlier ASFV vaccine studies focused on antigen-based approaches, aimed at inducing neutralizing serological responses (Table 1). The first recombinant ASFV protein to demonstrate protection against ASFV challenge was the baculovirus-expressed ASFV hemagglutinin (HA) protein, CD2v [44]. Pigs vaccinated 3 times with recombinant $C D 2 v$ proteins, then challenged with the virulent ASFV genotype I E75 strain, produced CD2v-specific antibodies, with one pig exhibiting virus-neutralizing activity. All three immunized pigs were protected from lethal challenge, although two animals did become viremic. This study, along with previous results, indicated that $C D 2 v$ was not a strong immunogenic antigen, and high doses of the protein would likely be required to induce good protection [45].

Many of the other subunit vaccine approaches since have focused on ASFV p54 and p30, two structural proteins involved in virus attachment and internalization, respectively, both of which are capable of inducing virus neutralizing antibodies [46]. Immunization of pigs with p54 or p30 antigen alone was not sufficient to protect pigs against virulent ASF challenge. However, pigs immunized with both, p54 and p30 together had a delay in onset of clinical symptoms, reduced viremia, and 3 out of 6 pigs were protected from virulent challenge with the E75 strain [46]. Similarly, immunization with a baculovirus-expressed p54/p30 fusion protein also reduced viremia and protected all pigs against virulent challenge with E75 [47]. 
Table 1. Antigen-based African swine fever virus (ASFV) vaccines evaluated in the swine model.

\begin{tabular}{|c|c|c|c|c|c|c|c|}
\hline Vaccine Type & ASFV Target Protein (Strain) & $\begin{array}{l}\text { Number of Immunizations; } \\
\text { Dose, Adjuvant }\end{array}$ & $\begin{array}{c}\text { Specific/Neutralizing } \\
\text { Antibodies }\end{array}$ & T Cell Response & $\begin{array}{c}\text { Challenge Strain; } \\
\text { Dose }\end{array}$ & Clinical Outcome & Ref. \\
\hline $\begin{array}{l}\text { Baculovirus-expressed } \\
\text { proteins }\end{array}$ & $\mathrm{CD} 2 \mathrm{v}(\mathrm{E} 75 \mathrm{CV})$ & $\begin{array}{l}3 \times ; 0.5-1 \times 10^{7} \mathrm{HAU}+ \\
\text { Freund's adjuvant }\end{array}$ & Yes; No & NA & $\mathrm{E} 75 ; 4 \times 10^{2}$ & $100 \%$ protection, $n=3 / 3$ & [44] \\
\hline $\begin{array}{l}\text { Baculovirus-expressed } \\
\text { proteins }\end{array}$ & p30, p54, p54 + p30 (E75) & $3 \times ; 100 \mu g+$ Freund's adjuvant & Yes; Yes & NA & $\mathrm{E} 75 ; 5 \times 10^{2}$ & $50 \%$ protection, $n=3 / 6$ & [46] \\
\hline $\begin{array}{l}\text { Baculovirus-expressed } \\
\text { proteins }\end{array}$ & p54/p30 chimera (E75) & $5 \times ; 100 \mu \mathrm{g}+$ Freund's adjuvant & Yes; Yes & NA & $\mathrm{E} 75 ; 5 \times 10^{2}$ & $100 \%$ protection, $n=2 / 2$ & {$[47]$} \\
\hline $\begin{array}{l}\text { Baculovirus-expressed } \\
\text { proteins }\end{array}$ & p54 + p30 + p72 + p22 (Pr4) & $4 \times ; 200 \mu \mathrm{g}+$ Freund's adjuvant & Yes; Yes & NA & $\operatorname{Pr} 4 ; 10^{4}$ & $\begin{array}{l}\text { Slight delay of clinical } \\
\text { disease and viremia; No } \\
\text { protection, }(n=0 / 6)\end{array}$ & [48] \\
\hline $\begin{array}{l}\text { HEK cell-expressed } \\
\text { proteins }\end{array}$ & p72, p54, p12 (Georgia 2007/1) & $2 \times ; 200 \mu \mathrm{g} /$ antigen + TS6 adjuvant & Yes; NA & Some & NA & NA & [49] \\
\hline
\end{tabular}

p30 also referred to as p32; $\mathrm{CD} 2 \mathrm{v}$ also referred to as $\mathrm{HA}=$ hemagglutinin; $\mathrm{NA}=$ not available. 
On the other hand, pigs immunized with a cocktail containing baculovirus-expressed proteins p30 + p54 + p72 + p22 were not protected from homologous challenge with the virulent ASFV Pr4 genotype I strain [48]. The results of that study indicated that neutralizing antibodies induced by these proteins are not sufficient for protection. This was supported by the earlier study with recombinant $\mathrm{CD} 2 \mathrm{v}$, in which protection in the absence of neutralizing antibodies was observed [44]. In line with these results, which indicated that factors other than neutralizing antibodies play a role in ASFV protection $[44,48]$, a study by Oura and colleagues demonstrated the importance of the cell-mediated, cytotoxic T lymphocyte (CTL) immune response for ASF protection [50]. In that study, pigs immunized with an attenuated ASFV strain and depleted of CD8+ T cells were not protected from homologous virulent challenge whereas non-depleted pigs were protected. Together, these results indicate that in addition to antibodies, a vaccine capable of stimulating a $\mathrm{T}$ cell-mediated response is likely required for conferring protection against ASFV.

\subsection{DNA Vaccines}

In contrast to antigen-based subunit vaccines, DNA vaccines are capable of inducing cell-mediated CTL immune responses, shown to play an important role in protection against ASFV [50]. As with ASFV subunit vaccine formulations, p54 and p30 have also been the target antigens for DNA vaccine approaches (Table 2).

Vaccination with a plasmid DNA encoding the p54/p30 fusion protein produced neither neutralizing nor $T$ cell responses and was not protective against challenge [51]. Pigs vaccinated with a DNA vaccine construct encoding a fusion of the swine leukocyte antigen SLA-II with p54/p30 developed broad immunological responses, including both specific antibodies and $\mathrm{T}$ cells, but were also not protected from challenge [52]. In an attempt to induce protection previously observed with the subunit vaccine of a similar formulation [47], the extracellular, soluble domain of the ASFV hemagglutinin protein, $\mathrm{CD} 2 \mathrm{v}$ (designated as sHA), was fused to the p54/p30 chimera [51]. Immunization with the sHA/p54/p30 construct did induce antigen-specific B- and T cell responses, but no protection was observed. However, the addition of ubiquitin to the sHA/p54/p30 fusion construct to target class I antigen presentation in vivo did confer protection against challenge in a small percentage of immunized pigs. Survival correlated with presence of $\mathrm{T}$ cells in the absence of detectable neutralizing antibodies, further supporting the importance of CTLs in protection against ASFV.

A DNA expression library established to identify T cell targets involved in ASFV protective immunity further supported the importance of CTL response in protection [53]. The library consisted of 80 ASFV open reading frames based on the genotype I Ba71v strain, fused with ubiquitin, representing approximately half of ASFV encoded proteins. Immunization of pigs with the DNA library conferred $60 \%$ protection against lethal challenge with the E75 strain. No specific anti-ASFV antibodies were detected following vaccination but were detectable after challenge along with ASFV-specific T cells. 
Table 2. DNA-based ASFV vaccines evaluated in the swine model.

\begin{tabular}{|c|c|c|c|c|c|c|c|}
\hline Vaccine Type & ASFV Target Protein (Strain) & $\begin{array}{c}\text { Number of Immunizations; } \\
\text { Dose }\end{array}$ & $\begin{array}{c}\text { Specific/Neutralizing } \\
\text { Antibodies }\end{array}$ & T Cell Response & $\begin{array}{l}\text { Challenge Strain; } \\
\text { Dose }\end{array}$ & Clinical Outcome & Ref. \\
\hline DNA (pCMV) & p54/p30 fusion (E75) & $3 x ; 600 \mu g$ & No; NA & No & E75; $10^{4}$ & No protection, $(n=0 / 4 ; n=0 / 4)$ & {$[51,52]$} \\
\hline DNA (pCMV) & SLA-II/p54/p30 fusion (E75) & $3 \times ; 600 \mu g$ & Yes; No & Yes & $\mathrm{E} 75 ; 10^{4}$ & No protection, $(n=0 / 4)$ & [52] \\
\hline DNA (pCMV) & sHA/p54/p30 fusion (E75) & $3 \times$ and $4 \times ; 600 \mu g$ & Yes; No & Yes & $\mathrm{E} 75 ; 10^{4}$ & $\begin{array}{l}\text { No protection, }(n=0 / 6) \\
\text { Partial protection, }(2\end{array}$ & [51] \\
\hline DNA (pCMV) & $\mathrm{Ub} / \mathrm{sHA} / \mathrm{p} 54 / \mathrm{p} 30$ fusion (E75) & $2 \times$ and $4 \times ; 600 \mu g$ & Not detectable & Yes & $\mathrm{E} 75 ; 10^{4}$ & $\begin{array}{l}\text { immunizations, } n=2 / 6 \text {; } 4 \\
\text { immunizations, } n=1 / 6 \text { ) }\end{array}$ & [51] \\
\hline DNA expression library & $\begin{array}{l}80 \text { ORFs fragments fused with } \\
\text { Ub (Ba71V) }\end{array}$ & $2 \times ; 600 \mu \mathrm{g}$ & Yes-after challenge; NA & Yes-after challenge & $\mathrm{E} 75 ; 10^{4}$ & $60 \%$ protection, $(n=6 / 10)$ & [53] \\
\hline
\end{tabular}

p30 also referred to as p32; CD2v also referred to as HA = hemagglutinin; $\mathrm{sHA}=$ extracellular/soluble domain; Ub = cellular ubiquitin; SLAII = swine leukocyte antigen class II DR molecule; $\mathrm{pCMV}=$ plasmid under cytomegalovirus promotor; $\mathrm{ORF}$ = open reading frames; $\mathrm{NA}=$ not available. 


\subsection{Virus Vectored Vaccines}

Another strategy to elicit both humoral and cell-mediated immune responses is the use of viral vectors. Safety is ensured by removing or replacing virulence genes of respective viruses with immunogens or making the virus vector replication incompetent. Moreover, viral vectors are inherently compatible for differentiating infected from vaccinated animals (DIVA), i.e., the virus vector encoded immunogens can serve as vaccine markers. To date, several vector-based approaches have been evaluated in pigs, yet few have been tested against virulent ASFV challenge (Table 3). A BacMam vector used for delivery of the sHA/p54/p30 fusion construct to pigs provided protection against sub-lethal challenge in 4 out of 6 pigs [54]. BacMam is a baculovirus-based vector with the ability to transduce mammalian cells to express the target genes. In the above study, no specific antibody response was detected, but protection correlated with a strong virus-specific $\mathrm{T}$ cell response.

Alphavirus replicon particles (RPs) expressing p30, p54, and p72 have also been used to immunize pigs [55]. Vaccinated pigs developed strong antibodies against $\mathrm{p} 30$, and positive virus neutralization with sera from pigs immunized with p30 suggested a low level of neutralizing activity. Alphavirus-p54 vaccinated pigs developed low levels of anti-p54 antibodies, and no antigen-specific antibodies were detected from sera of p72 immunized pigs. However, the addition of the sHA domain of CD2v to p72 did result in detectable levels of antibodies against p72. Expression levels of each of the antigens in vitro correlated with the immune responses generated. Unfortunately, this study did not include data on cell-mediated immune responses, and protection against virulent challenge was not tested.

Immunogenicity studies with antigen cocktails delivered by virus vectors have also been evaluated in swine. Cocktails of adenovirus delivered ASFV antigens p30 + p54 + p72 + pp62, and ASFV genes $\mathrm{A} 151 \mathrm{R}+\mathrm{B} 119 \mathrm{~L}+\mathrm{B} 602 \mathrm{~L}+\mathrm{EP} 402 \mathrm{R} \Delta \mathrm{PRR}+\mathrm{B} 438 \mathrm{~L}+\mathrm{K} 205 \mathrm{R}+\mathrm{A} 104 \mathrm{R}$ induced both strong antigen-specific humoral and cellular immune responses [56,57]. Another ASF vaccine cocktail consisted of modified Vaccinia virus Ankara-vectored ASFV antigens p72, CD2v, and C-type lectin [49]. Although no antigen-specific antibodies were induced, $\mathrm{T}$ cell responses for each of the antigens were detected in immunized pigs. However, none of these immunization studies were tested against virulent virus challenge.

A mouse model was used to evaluate a recombinant Newcastle disease virus expressing p72 and was shown to be safe and immunogenic [58]. Yet it is difficult to predict how these results translate to swine, as observed previously with a p54/p30 DNA vaccine, which was found to be immunogenic in the mouse model but not in pigs [51,52]. This highlights the importance of evaluation of vaccine prototypes using the target animal species, the pig. 
Table 3. Virus vector-based ASFV vaccines evaluated in the swine model.

\begin{tabular}{|c|c|c|c|c|c|c|c|}
\hline Vaccine Type & ASFV Target Protein (Strain) & $\begin{array}{c}\text { Number of Immunizations; Dose, } \\
\text { Adjuvant }\end{array}$ & $\begin{array}{c}\text { Specific/Neutralizing } \\
\text { Antibodies }\end{array}$ & $\begin{array}{c}\text { T Cell } \\
\text { Response }\end{array}$ & $\begin{array}{l}\text { Challenge Strain; } \\
\text { Dose }\end{array}$ & Clinical Outcome & Ref. \\
\hline BacMam & sHA/p54/p30 fusion (E75) & $3 \times ; 10^{7} \mathrm{PFU}$ & $\begin{array}{l}\text { No (only after } \\
\text { challenge); No }\end{array}$ & Yes & $\begin{array}{l}\text { E75; } 2 x \text { sublethal } \\
\text { challenge } 10^{2}\end{array}$ & $\begin{array}{l}\text { Partial protection, } \\
\quad(n=4 / 6)\end{array}$ & [54] \\
\hline Adenovirus & p30+p54+pp62+p72 (Georgia 2007/1) & $\begin{array}{c}2 \times ; 10^{10} \text { or } 10^{11} \text { per Ad5-antigen + } \\
\text { adjuvants }\end{array}$ & Yes; NA & Yes & NA & NA & [56] \\
\hline Adenovirus & $\begin{array}{c}\text { A151R+B119L+B602L+ } \\
\text { EP402R } \triangle P R R+B 438 L+K 205 R+A 104 R \\
(\text { Georgia 2007/1) }\end{array}$ & $2 \times ; 10^{11}$ per Ad5-antigen + adjuvant & Yes; NA & Yes & NA & NA & [57] \\
\hline Vaccinia virus Ankara & $\begin{array}{l}\text { p72, C-type Lectin, CD2v (Georgia } \\
\text { 2007/1) }\end{array}$ & $2 \times ;$ rVACV-ASFV $10^{7}$ TCID $_{50}$ & No; NA & Yes & NA & NA & [49] \\
\hline Alphavirus RPs & p30, p54, p72, sHA/72 (Ba71V) & $3 \times: 2-4.5 \times 10^{7} \mathrm{RPs}$ & Yes; NA & NA & NA & NA & [55] \\
\hline
\end{tabular}

p30 also referred to as $\mathrm{p} 32 ; \mathrm{CD} 2 \mathrm{v}$ also referred to as HA = hemagglutinin; sHA = extracellular/soluble domain; rVACV = recombinant vaccinia virus; RPs = replicon particles; 


\subsection{Combination and Heterologous Prime-Boost Vaccination Approaches}

Combination vaccines and heterologous prime-boost strategies which incorporate the use of two different vaccine platforms to induce better humoral and cellular immune responses have also been investigated and are summarized in Table 4. One such approach is a combined DNA-protein vaccine. Immunogenicity of various combinations of antigens and plasmid DNAs in swine was determined [59], and the antigens which induced neutralizing antibodies and $\mathrm{T}$ cell responses were subsequently tested as a DNA-protein vaccine cocktail in challenge experiments [60]. The vaccine cocktail contained 7 different ASFV targets-p15, p35, p54, p72, CD2v, p30, and p17-and was delivered 3 times prior to challenge. Vaccinated pigs produced antibodies against ASFV antigens p15, p35, and p54, but no neutralizing activity was observed. Only few antigen-specific T cells were detected after vaccination, and pigs were not protected following lethal challenge with the Armenia 2007 strain [60].

Other approaches have incorporated virus vector and DNA or protein-based vaccine platforms. A heterologous prime-boost approach, consisting of priming pigs with 47 plasmid DNA constructs and boosting with 47 recombinant vaccinia viruses, was employed to identify potential protective immunogens [61]. A total of 47 antigens were represented and tested for the ability to induce humoral and cellular immune responses. T cell responses and specific antibodies were detected for many of the antigens, but no neutralizing activity was detected, even in the presence of anti-p30, -p54 and -p72 antibodies. Importantly, the number of antigens included in the cocktails did not appear to affect responses to individual antigens. Vaccinated pigs were tested against virulent challenge with the genotype II Georgia 2007/1 strain. Although none of the vaccinated pigs were protected, virus levels were reduced in blood and certain tissues [61].

A modified Vaccinia Ankara virus vector expressing individual p72, CD2v, and C-type lectin ASFV antigens, followed by a boost with the corresponding mammalian cell-expressed proteins, also yielded $T$ cell responses against each of the antigens, particularly for p72 [49]. However, protection against virus challenge was not tested. Finally, a heterologous prime-boost approach incorporating the alphavirus delivered ASFV p30 and an attenuated ASFV strain induced a strong anti-p30 antibody response as well as had the capacity to at least partially neutralize virus infection in vitro; however, $\mathrm{T}$ cell responses and protection against virus challenge were not evaluated in that study [55]. Evaluating these vaccination studies against virulent ASFV challenge in swine will be critical to determine the true protective potential of each of these strategies.

\section{Immune Determinants of Protection against ASFV}

The correlates of protection against ASFV are still not completely understood. Results for the role of ASFV neutralizing antibodies in protection are somewhat conflicting [62]. A strong neutralizing antibody response has been associated with protection $[46,47]$ but does not appear to define it, since protection was also achieved the absence of neutralizing antibodies $[44,51,53,54]$. Furthermore, the presence of neutralizing antibodies in another study was shown not to be sufficient for protection [48]. Exacerbation of ASFV infection and disease in immunized pigs associated with high levels of non-neutralizing antibodies has also been documented and is discussed in the next section.

A study by Oura and colleagues demonstrated that CD8+ T cells play an important role in ASFV protection, and a clear correlation exists between protection and the presence of ASFV-specific T cells $[50,51,53,54]$. Natural killer (NK) cells also appear to play a role in protection. High levels of NK cell activity in pigs immunized with the naturally attenuated, nonhemadsorbing NH/P68 strain correlated with protection against virulent challenge [40]. Thus, both neutralizing antibodies and strong cell-mediated immune responses may be important for protection against ASFV. 
Table 4. Combination and heterologous prime-boost ASFV vaccine strategies.

\begin{tabular}{|c|c|c|c|c|c|c|c|}
\hline Vaccine Type & ASFV Target Protein (Strain) & $\begin{array}{c}\text { Number of Immunizations; Dose, } \\
\text { Adjuvant }\end{array}$ & $\begin{array}{l}\text { Specific/Neutralizing } \\
\text { Antibodies }\end{array}$ & $\begin{array}{c}\text { T Cell } \\
\text { Response }\end{array}$ & $\begin{array}{c}\text { Challenge Strain; } \\
\text { Dose }\end{array}$ & Clinical Outcome & Ref. \\
\hline \multicolumn{8}{|l|}{ Combination } \\
\hline DNA-Protein & $\begin{array}{l}\text { Combinations of DNA and protein: } \\
\text { p15, p30, p35, p54, p72, CD2v, } \\
\text { CP312R, g5R (Georgia 2007/1; Ba71V) }\end{array}$ & $\begin{array}{c}3 \times ; 100 \mu g \text { per DNA, } 100 \mu \mathrm{g} \text { protein }+ \\
\text { ISA25 adjuvant }\end{array}$ & Yes; Yes & Some & NA & NA & [59] \\
\hline DNA-Protein & $\begin{array}{l}\text { Proteins: p15, p35, p54, p17; DNA: } \\
\text { CD2v, p72, p54, p30, p17 } \\
\text { (Georgia 2007/1; Ba71V) }\end{array}$ & $\begin{array}{c}3 \times ; 100 \mu \mathrm{g} \text { per DNA, } 100 \mu \mathrm{g} \text { protein }+ \\
\text { ISA25 adjuvant }\end{array}$ & Yes; No & Some & $\begin{array}{c}\text { Armenia 2007; } 360 \\
\text { HAU }\end{array}$ & $\begin{array}{l}\text { No protection; } \\
\text { disease } \\
\text { enhancement }\end{array}$ & [60] \\
\hline \multicolumn{8}{|l|}{ Heterologous Prime-Boost } \\
\hline $\begin{array}{l}\text { DNA prime + vaccinia } \\
\text { virus boost }\end{array}$ & 47 antigens (Georgia 2007/1) & $\begin{array}{c}\text { Prime 2x: } 10 \mu \mathrm{g} \text { pCMV-DNA + CpG } \\
\text { oligo adjuvant; } \\
\text { Boost } 2 \times: 10^{8} \text { PFU rVACV-ASFV }\end{array}$ & Yes; No & Yes & $\begin{array}{l}\text { Georgia 2007/1; } \\
\qquad 10^{4}\end{array}$ & $\begin{array}{l}\text { No protection; } \\
\text { reduced viral load, } \\
\text { higher clinical } \\
\text { scores }\end{array}$ & [61] \\
\hline $\begin{array}{l}\text { Vaccinia virus prime }+ \\
\text { protein boost }\end{array}$ & $\begin{array}{l}\text { p72, C-type Lectin, CD2v } \\
\text { (Georgia 2007/1) }\end{array}$ & $\begin{array}{l}\text { Prime: rVACV-ASFV } 10^{7} \text { TCID }_{50} \\
\text { Boost: } 200 \mu g / \text { antigen + TS6 adjuvant }\end{array}$ & NA & Yes & NA & NA & [49] \\
\hline $\begin{array}{l}\text { Alphavirus RP prime }+ \\
\text { live attenuated } \\
\text { ASFV boost }\end{array}$ & p30 (Ba71V) + OURT88/3 & $\begin{array}{c}\text { Prime } 2 \times: 2-4.5 \times 10^{7} \text { RPs; Boost: } 10^{4} \\
\text { TCID }_{50} \text { OURT } 88 / 3\end{array}$ & Yes; Yes & NA & NA & NA & [55] \\
\hline
\end{tabular}

p30 also referred to as p32; CD2v also referred to as HA = hemagglutinin; sHA = extracellular/soluble domain; rVACV = recombinant vaccinia virus; RPs = replicon particles; NA $=$ not available. 


\subsection{ASFV Antigen Targets}

Identification of ASFV targets that play a role in protection is important for the development of an effective vaccine against ASFV. Several immunogenic ASFV targets have been identified. Still, it is not completely clear which ones play a significant role in protection against ASFV. Table 5 shows ASFV antigens identified by reactivity with sera from ASFV infected swine. Of 14 viral proteins initially found to be immune reactive against infected sera from domestic swine and bush pigs [63], 12 were further tested in a longitudinal serological study with pigs infected with the attenuated NH/P68 strain [41]. Those studies showed overall poor antibody responses to the following ASFV recombinant proteins: K196R/thymidine kinase, K78R/p10, C44L, intermediate antibody responses to B646L/p72, CP204L/p30, CP312R, NP419L/DNA ligase, and F334L/ribonucleotide reductase; and strong responses to E183L/p54, K205R, A104R/viral histone, and B602L/p72 chaperone, the latter of which were further evaluated and antigenicity confirmed with sera from swine infected with virulent virus [62].

Table 5. Antigens recognized by ASFV infected pig sera.

\begin{tabular}{|c|c|c|c|c|c|}
\hline ASFV Gene & Product & ASFV Strains & IgG & IgM & Ref. \\
\hline \multicolumn{6}{|c|}{ Structural proteins } \\
\hline A104R & Viral histone-like & $\begin{array}{c}\text { Malta, Malawi, OURT88; NH/P68; Uganda, } \\
\text { E70, E75 }\end{array}$ & Yes & Yes & {$[41,63,64]$} \\
\hline B646L & p72, major capsid & Malta, Malawi, OURT88; NH/P68 & Yes & NA & {$[41,63]$} \\
\hline CP204L & $\begin{array}{l}\text { p30, virus entry } \\
\text { phosphoprotein }\end{array}$ & Malta, Malawi, OURT88; NH/P68 & Yes & NA & {$[41,63]$} \\
\hline E183L & p54, inner envelope & $\begin{array}{c}\text { Malta, Malawi, OURT88; NH/P68; Uganda, } \\
\text { E70, E75 }\end{array}$ & Yes & Yes & {$[41,63,64]$} \\
\hline K78R & p10, DNA- binding & Malta, Malawi, OURT88 & NA & NA & {$[41,63]$} \\
\hline \multicolumn{6}{|c|}{ Nonstructural proteins } \\
\hline B602L & p72 chaperone & $\begin{array}{c}\text { Malta, Malawi, OURT88; NH/P68; Uganda, } \\
\text { E70, E75 }\end{array}$ & Yes & Yes & {$[41,63,64]$} \\
\hline F334L & Ribonucleotide reductase & Malta, Malawi, OURT88; NH/P68 & Yes & NA & {$[41,63]$} \\
\hline K196R & Thymidine kinase & Malta, Malawi, OURT88 & NA & NA & {$[41,63]$} \\
\hline NP419L & DNA ligase & Malta, Malawi, OURT88; NH/P68 & Yes & NA & {$[41,63]$} \\
\hline \multicolumn{6}{|c|}{ Unassigned proteins } \\
\hline K205R & Unknown & $\begin{array}{c}\text { Malta, Malawi, OURT88; NH/P68; Uganda, } \\
\text { E70, E75 }\end{array}$ & Yes & Yes & {$[41,63,64]$} \\
\hline E184L & Unknown & Malta, Malawi, OURT88 & NA & NA & [63] \\
\hline CP312R & Unknown & Malta, Malawi, OURT88; NH/P68 & Yes & NA & {$[41,63]$} \\
\hline $\mathrm{C} 44 \mathrm{~L}$ & Unknown & Malta, Malawi, OURT88 & NA & NA & {$[41,63]$} \\
\hline
\end{tabular}

Of these viral proteins recognized by infected pig sera, p30, p54, p72, A104R, B602L, NP419L, and K205R have been further investigated in immunogenicity and vaccine studies, in addition to a number of other ASFV targets. Table 5 summarizes ASFV targets that have been used in various vaccine formulations and which have been shown to induce either antibody or cell-mediated responses, or both. The main ASFV antigens known to induce neutralizing antibodies are p72, p54, and p30 [46,48,65-67] and are also the most extensively investigated ASFV antigens in terms of immunogenicity studies and for development of ASFV vaccines and diagnostics. Other antigens/immunogens confirmed by multiple studies include CP530R/pp62 and its derivate p15, EP402R/CD2v, B602L/p72 chaperone, and EP153R/C-type lectin (see Table 6).

An immunogenicity screen of 47 different ASFV antigens found that previously identified CP204L/p30, E183L/p54, B602L/p72 chaperone, CP530R/pp62, and newly identified EP364R, F317L, MGF505-4R, MGF360-11L, CP2475L/pp220, E119L/virion protein, F1055L/helicase, G1211R/DNA polymerase, and NP1450L/RNA polymerase 1 to consistently induce high cellular immune responses [61]. Antigens CP204L/p30, D117L/p17, EP153R/C-type lectin, and L10L/KP117R-related protein consistently induced high levels of antigen-specific antibodies; however, no neutralizing activity was detected despite the presence of specific antibodies to known neutralizing antigens p30, p54, and p72. 
Table 6. Identified ASFV immunogens.

\begin{tabular}{|c|c|c|c|c|c|}
\hline ASFV Gene & Product & Delivery Method & Antibody Response & T Cell Response & Reference \\
\hline \multicolumn{6}{|l|}{ Structural proteins } \\
\hline B438L & p49, capsid formation & Vector & Yes & Yes & {$[57,61]$} \\
\hline B646L & p72, major capsid & Protein, DNA, Vector & Yes & Yes & {$[48,49,55,56,59,60]$} \\
\hline CP204L & p30, virus entry phosphoprotein & Protein, DNA, Vector & Yes & Yes & {$[46,47,49,51,52,55,56,59-61]$} \\
\hline \multirow[t]{3}{*}{ CP530R } & pp62, core shell polyprotein & DNA, Vector & Yes & Yes & {$[56,61]$} \\
\hline & p15 & Protein, DNA & Yes & No & {$[59,60]$} \\
\hline & p35 & Protein, DNA & Yes & No & {$[59,60]$} \\
\hline CP2475L & $\begin{array}{l}\text { pp220, core shell polyprotein: p150, } \\
\text { p37, p14, p34 }\end{array}$ & DNA, Vector & NA & Yes & {$[61]$} \\
\hline D117L & p17, inner envelope & DNA, Vector & Yes & low & [61] \\
\hline E120R & $\mathrm{p} 14.5$ & DNA, Vector & Yes & NA & [61] \\
\hline E183L & p54, inner envelope & Protein, DNA, Vector & Yes & Yes & {$[46,47,49,51,52,55,56,59,60]$} \\
\hline E199L & j18L, virion protein & DNA, Vector & NA & Yes & [61] \\
\hline EP402R & CD2v, outer envelope & Protein, Vector & Yes & Yes & {$[44,49,59,61]$} \\
\hline H108R & Inner envelope & DNA, Vector & Yes & NA & [61] \\
\hline KP177R & p22, outer envelope & Protein & Yes & Yes & {$[48,61]$} \\
\hline O61R & p12, envelope & Protein & Yes & Yes & {$[49,61]$} \\
\hline \multicolumn{6}{|c|}{ Nonstructural proteins } \\
\hline A151R & viral replication & Vector & Yes & Yes & [57] \\
\hline B119L & 9GL, virus assembly & Vector & Yes & Yes & [57] \\
\hline B602L & p72 chaperone & DNA, Vector & Yes & Yes & {$[57,61]$} \\
\hline EP153R & C-type lectin & DNA, Vector & Yes & Yes & {$[49,61]$} \\
\hline F1055L & Helicase & DNA, Vector & NA & Yes & [61] \\
\hline G1211R & DNA polymerase & DNA, Vector & NA & Yes & [61] \\
\hline L10L & KP117R-related & DNA, Vector & Yes & NA & [61] \\
\hline MGF360-11L & KP362L & DNA, Vector & NA & Yes & [61] \\
\hline MGF505-4R & NA & DNA, Vector & NA & Yes & [61] \\
\hline NP419L & DNA ligase & DNA, Vector & NA & Yes & [61] \\
\hline NP1450L & RNA polymerase subunit 1 & DNA, Vector & NA & Yes & [61] \\
\hline \multicolumn{6}{|c|}{ Unassigned proteins } \\
\hline & K205R/A104R & Vector & Yes & Yes & [57] \\
\hline & EP364R & DNA, Vector & NA & Yes & [61] \\
\hline & F317L & DNA, Vector & NA & Yes & [61] \\
\hline
\end{tabular}

$\mathrm{NA}=$ not available 


\subsection{ASFV Immune-Mediated Enhancement of Disease}

Several vaccine-challenge studies suggest immune-mediated enhancement of ASFV infection and disease. Which factors are responsible is not clearly understood, but high levels of antibodies appear to play a role, and several ASFV immunogens have been associated with enhanced infection and/or pathology (Table 7). Elevated antibody levels in pigs developing chronic ASFV have been demonstrated previously [68], and systemic immune overstimulation appears to be associated with chronic or persistent ASFV infections [69]. In a study by Leitao et al. (2001), pigs immunized with the attenuated NH/P68 strain were divided into 2 groups based on clinical and immunological criteria: asymptomatic animals versus those that developed chronic clinical disease [40]. Clear differences were observed between ASFV-specific antibody titers and the level of NK cell activity of the two clinically defined groups. Asymptomatic pigs had high NK cell activity but relatively low anti-ASFV antibodies. By contrast, animals that developed chronic type lesions exhibited late fever and viremia, had high levels of ASFV-specific antibodies, and relatively normal NK cell activity levels. The elevated antibody levels observed involved IgG1, IgG2, IgM, and IgA subclasses of immunoglobulins. In another study which screened serological responses of NH/P68 infected pigs against 12 ASFV recombinant antigens, higher antibody titers against ASFV targets NP419L, CP312R, K196R, K205R, and especially p72 appeared to correlate with the occurrence of lesions observed in chronically infected animals [41]. Interestingly, higher antibody levels, including total $\operatorname{IgG}$ as well as IgG1, IgG2, and IgM responses against A104R tended to be associated with asymptomatic pigs. 
Table 7. ASFV immunogens associated with immune-enhanced pathology

\begin{tabular}{|c|c|c|c|c|c|}
\hline ASFV Gene & Product & Clinical Associations & Antibody Response & T Cell Response & Ref. \\
\hline \multicolumn{6}{|c|}{ Structural proteins } \\
\hline B438L & p49, capsid formation & Higher clinical scores & Yes; & NA & [61] \\
\hline \multirow[t]{3}{*}{ B646L } & p72, major capsid & Chronic lesions & Yes, high level & NA & [41] \\
\hline & & Enhanced infection in vitro and disease in vivo & Yes & No & [60] \\
\hline & & Higher clinical scores & Yes, low level & Low & [61] \\
\hline \multirow[t]{5}{*}{ CP204L } & p30, virus entry phosphoprotein & Chronic lesions & Yes, high level & NA & [41] \\
\hline & & Hyperimmunization associated with fewer protected pigs & Not detectable & Yes & [51] \\
\hline & & Higher viremia in pigs; enhanced infection in vitro & Yes & Yes & [52] \\
\hline & & Enhanced infection in vitro and disease in vivo & Yes & No & [60] \\
\hline & & Higher clinical scores & Yes, high level & Yes & [61] \\
\hline CP530R & p 15 and $\mathrm{p} 35$ & Enhanced infection in vitro and disease in vivo & Yes & Few & [60] \\
\hline CP2475L & $\begin{array}{l}\text { pp220, core shell polyprotein: } 150, \\
\text { p37, p14, p34 }\end{array}$ & Higher clinical scores & NA & Yes & {$[61]$} \\
\hline \multirow[t]{2}{*}{ D117L } & p17, inner envelope & Enhanced infection in vitro and disease in vivo & Not detectable & No & [60] \\
\hline & & Higher clinical scores & Yes, high level & Low & [61] \\
\hline E120R & p14.5 & Higher clinical scores & Yes & NA & [61] \\
\hline \multirow{5}{*}{ E183L } & p54, inner envelope & Chronic lesions & Yes, high level & NA & [41] \\
\hline & & Hyperimmunization associated with fewer protected pigs & Not detectable & Yes & [51] \\
\hline & & Higher viremia in pigs; enhanced infection in vitro & Yes & Yes & [52] \\
\hline & & Enhanced infection in vitro and disease in vivo & Yes & No & [60] \\
\hline & & Higher clinical scores & Yes, low level & Yes & [61] \\
\hline \multirow{2}{*}{ EP402R } & & Enhanced infection in vitro and disease in vivo & NA & No & [60] \\
\hline & & Higher clinical scores & Yes & Low & [61] \\
\hline H108R & Inner envelope & Higher clinical scores & Yes & NA & [61] \\
\hline KP177R & p22, outer envelope & Higher clinical scores & Yes & Yes & [61] \\
\hline O61R & p12, envelope & Higher clinical scores & Yes & NA & [61] \\
\hline \multicolumn{6}{|c|}{ Nonstructural proteins } \\
\hline B602L & p72 chaperone & Higher clinical scores & Yes & Yes & [61] \\
\hline EP153R & C-type lectin & Higher clinical scores & Yes, high level & NA & [61] \\
\hline F1055L & Helicase & Higher clinical scores & NA & Yes & [61] \\
\hline G1211R & DNA polymerase & Higher clinical scores & NA & YES & [61] \\
\hline K196R & Thymidine kinase & Chronic lesions & Yes, high level & NA & [41] \\
\hline L10L & KP117R-related & Higher clinical scores & Yes, high level & NA & [61] \\
\hline
\end{tabular}


Table 7. Cont.

\begin{tabular}{|c|c|c|c|c|c|}
\hline ASFV Gene & Product & Clinical Associations & Antibody Response & T Cell Response & Ref. \\
\hline MGF360-11L & KP362L & Higher clinical scores & NA & Yes & [61] \\
\hline MGF505-4R & NA & Higher clinical scores & NA & Yes & [61] \\
\hline NP1450L & RNA polymerase subunit 1 & Higher clinical scores & NA & Yes & [61] \\
\hline \multirow[t]{2}{*}{ NP419L } & DNA ligase & Chronic lesions & Yes, high level & NA & [41] \\
\hline & & Higher clinical scores & NA & Yes & [61] \\
\hline \multicolumn{6}{|c|}{ Unassigned proteins } \\
\hline CP312R & & Chronic lesions & Yes, high level & NA & [41] \\
\hline K205R & & Chronic lesions & Yes, high level & NA & [41] \\
\hline EP364R & & Higher clinical scores & NA & Yes & [61] \\
\hline F317L & & Higher clinical scores & NA & Yes & [61] \\
\hline
\end{tabular}

NA = not available. 
Pigs vaccinated with a DNA vaccine construct encoding a fusion of the swine leukocyte antigen SLA-II and ASFV p54 and p30 developed broad immunological responses, including both antigen-specific antibodies and T cells [52]. However, following challenge, vaccinated pigs were not protected and had statistically higher viremia compared to the control animals, especially at 3 days post-infection. Furthermore, immune sera from the vaccinated animals did not neutralize but appeared to enhance infection of macrophages in vitro.

A DNA chimera of the extracellular domain of ASFV CD2v (sHA), p54, and p30 induced specific, non-neutralizing antibodies but did not confer protection [51]. However, the addition of ubiquitin $(\mathrm{Ub})$ to the fusion construct modified the induction of immune responses in vaccinated pigs and conferred partial protection, which correlated with activated T cell responses [51]. Hyperimmunization also appeared to be associated with reduced protection. Although not statistically significant, four doses of the DNA Ub/sHA/p54/p30 construct resulted in fewer pigs protected from challenge, as compared to two immunizations of the same vaccine (Table 2), which was observed in two independent experiments [51]. The hypothesis was that the extra vaccination may have induced low levels of immunopathological antibodies that may have in turn reduced the number of pigs protected from challenge [51].

Statistically higher clinical scores were observed in immunized pigs with ASFV antigen pools by DNA prime and boost with recombinant vaccinia virus compared to control pigs [61]. Immunization induced both antibody and $\mathrm{T}$ cell responses and also reduced viral loads in the blood and some tissues, but pigs were not protected from challenge. No virus neutralizing activity was detected.

In an ASFV vaccine study evaluating adjuvants combined with inactivated virus, high antibody titers that lacked neutralizing activity correlated with an accelerated disease course [31]. Vaccinees were not protected following homologous ASFV challenge, and in fact, enhanced infection and disease was observed. Similarly, pigs immunized with a cocktail of ASFV DNA and ASFV proteins also had an accelerated disease course compared to nonvaccinated controls [60]. Vaccinated pigs had earlier onset of clinical symptoms, viremia, and death following lethal challenge. Pathological scores also tended to be higher in vaccinated versus control pigs. Immunological analyses showed vaccination induced minimal T cell responses but detectable levels of antigen-specific antibodies, which were unable to neutralize virus and instead enhanced ASFV infection in vitro [60].

Taken together, the results of these studies suggest that an overproduction of antibodies is likely detrimental and exacerbates disease progression, especially in the absence of a strong cell-mediated immune response. However, it is still not clear whether neutralizing and/or non-neutralizing antibodies are responsible for enhancement of infection and disease. One possible explanation is antibody-dependent enhancement (ADE) of infection, mediated via IgG antibody-antigen complexes and Fc $\gamma$-receptor signaling, which is known to occur with microorganisms that replicate in macrophages, like ASFV, porcine reproductive and respiratory virus, dengue virus, and a number of other viral pathogens [70-73]. Studies to investigate ASFV immune enhancement and the mechanism involved in ASFV pathogenesis are warranted and will be beneficial for the development of safer and more effective ASFV vaccines.

\section{Conclusions}

Various vaccine strategies for ASF have been investigated with a wide variety of ASFV-specific targets evaluated. Yet, many of these strategies have not been tested against virus challenge. Which ASFV targets play a significant role in virulence and immunopathology or protection is still largely unknown. Expanding our understanding of the ASFV proteome and the functions of individual proteins will be important for rationally designing targeted vaccine approaches. Furthermore, finding the right balance between both antibody- and cell-mediated ASFV immune responses is clearly important. Immune overstimulation appears to be the key factor affecting the disease course of ASF, and high levels of antibodies appear to have a particularly detrimental effect on clinical outcome and protection. Shifting the focus to less immunogenic ASFV antigens and the identification of novel 
neutralizing ASFV antigens or epitopes may also prove to be beneficial. For example, p30 is capable of inducing a strong antibody response; however, only a portion of these antibodies appear to be virus neutralizing. Determining which type of antibodies are detrimental and perhaps the identification of neutralizing and non-neutralizing epitopes within individual antigens could be beneficial for designing a more targeted immune response to improve protection. Nonetheless, induction of strong cell-mediated immunity, such as NK and T cell responses, appears to remain a critical component for designing a safe and efficacious ASFV vaccine.

Author Contributions: Authors N.N.G. and J.A.R. contributed to the conceptualization, writing, review, and editing.

Funding: This research was funded by grants from the U.S. Department of Homeland Security under Grant Award Number DHS-2010-ST-061-AG0001 for the Center of Excellence for Emerging and Zoonotic Animal Disease and the State of Kansas National Bio and Agro-Defense Facility transition funds.

Acknowledgments: The authors like to thank Y. Revilla for her continued collaboration and the invitation to contribute an article to this Special Issue.

Conflicts of Interest: The authors declare no conflict of interest.

\section{References}

1. Penrith, M.L.; Bastos, A.D.; Etter, E.M.C.; Beltran-Alcrudo, D. Epidemiology of African swine fever in Africa today: Sylvatic cycle versus socio-economic imperatives. Transbound Emerg. Dis. 2019, 66, 672-686. [CrossRef] [PubMed]

2. Blome, S.; Gabriel, C.; Beer, M. Pathogenesis of African swine fever in domestic pigs and European wild boar. Virus Res. 2013, 173, 122-130. [CrossRef] [PubMed]

3. Pikalo, J.; Zani, L.; Huhr, J.; Beer, M.; Blome, S. Pathogenesis of African swine fever in domestic pigs and European wild boar-Lessons learned from recent animal trials. Virus Res. 2019. [CrossRef] [PubMed]

4. Costard, S.; Wieland, B.; de Glanville, W.; Jori, F.; Rowlands, R.; Vosloo, W.; Roger, F.; Pfeiffer, D.U.; Dixon, L.K. African swine fever: How can global spread be prevented? Philos. Trans. R. Soc. Lond. B Biol. Sci. 2009, 364, 2683-2696. [CrossRef] [PubMed]

5. Cwynar, P.; Stojkov, J.; Wlazlak, K. African Swine Fever Status in Europe. Viruses 2019, 11, 310. [CrossRef] [PubMed]

6. Rowlands, R.J.; Michaud, V.; Heath, L.; Hutchings, G.; Oura, C.; Vosloo, W.; Dwarka, R.; Onashvili, T.; Albina, E.; Dixon, L.K. African swine fever virus isolate, Georgia, 2007. Emerg. Infect. Dis. 2008, 14, 1870-1874. [CrossRef] [PubMed]

7. Gogin, A.; Gerasimov, V.; Malogolovkin, A.; Kolbasov, D. African swine fever in the North Caucasus region and the Russian Federation in years 2007-2012. Virus Res. 2013, 173, 198-203. [CrossRef] [PubMed]

8. Costard, S.; Mur, L.; Lubroth, J.; Sanchez-Vizcaino, J.M.; Pfeiffer, D.U. Epidemiology of African swine fever virus. Virus Res. 2013, 173, 191-197. [CrossRef] [PubMed]

9. Linden, A.; Licoppe, A.; Volpe, R.; Paternostre, J.; Lesenfants, C.; Cassart, D.; Garigliany, M.; Tignon, M.; van den Berg, T.; Desmecht, D.; et al. Summer 2018: African swine fever virus hits north-western Europe. Transbound. Emerg. Dis. 2019, 66, 54-55. [CrossRef] [PubMed]

10. Zhou, X.; Li, N.; Luo, Y.; Liu, Y.; Miao, F.; Chen, T.; Zhang, S.; Cao, P.; Li, X.; Tian, K.; et al. Emergence of African Swine Fever in China, 2018. Transbound. Emerg. Dis. 2018, 65, 1482-1484. [CrossRef]

11. World Organization for Animal Health. World Animal Health Information Database. Summary of Immediate Notification and Follow-Ups. 2019. Available online: https:/www.oie.int/wahis_2/public/wahid. php/Diseaseinformation/Immsummary (accessed on 23 April 2019).

12. Quembo, C.J.; Jori, F.; Vosloo, W.; Heath, L. Genetic characterization of African swine fever virus isolates from soft ticks at the wildlife/domestic interface in Mozambique and identification of a novel genotype. Transbound. Emerg. Dis. 2018, 65, 420-431. [CrossRef] [PubMed]

13. Achenbach, J.E.; Gallardo, C.; Nieto-Pelegrin, E.; Rivera-Arroyo, B.; Degefa-Negi, T.; Arias, M.; Jenberie, S.; Mulisa, D.D.; Gizaw, D.; Gelaye, E.; et al. Identification of a New Genotype of African Swine Fever Virus in Domestic Pigs from Ethiopia. Transbound. Emerg. Dis. 2017, 64, 1393-1404. [CrossRef] [PubMed] 
14. Malogolovkin, A.; Burmakina, G.; Titov, I.; Sereda, A.; Gogin, A.; Baryshnikova, E.; Kolbasov, D. Comparative analysis of African swine fever virus genotypes and serogroups. Emerg. Infect. Dis. 2015, 21, 312-315. [CrossRef] [PubMed]

15. Malogolovkin, A.; Burmakina, G.; Tulman, E.R.; Delhon, G.; Diel, D.G.; Salnikov, N.; Kutish, G.F.; Kolbasov, D.; Rock, D.L. African swine fever virus CD2v and C-type lectin gene loci mediate serological specificity. J. Gen. Virol. 2015, 96, 866-873. [CrossRef] [PubMed]

16. Chapman, D.A.; Darby, A.C.; Da Silva, M.; Upton, C.; Radford, A.D.; Dixon, L.K. Genomic analysis of highly virulent Georgia 2007/1 isolate of African swine fever virus. Emerg. Infect. Dis. 2011, 17, 599-605. [CrossRef]

17. Gallardo, C.; Fernandez-Pinero, J.; Pelayo, V.; Gazaev, I.; Markowska-Daniel, I.; Pridotkas, G.; Nieto, R.; Fernandez-Pacheco, P.; Bokhan, S.; Nevolko, O.; et al. Genetic variation among African swine fever genotype II viruses, eastern and central Europe. Emerg. Infect. Dis. 2014, 20, 1544-1547. [CrossRef] [PubMed]

18. Garigliany, M.; Desmecht, D.; Tignon, M.; Cassart, D.; Lesenfant, C.; Paternostre, J.; Volpe, R.; Cay, A.B.; van den Berg, T.; Linden, A. Phylogeographic Analysis of African Swine Fever Virus, Western Europe, 2018. Emerg. Infect. Dis. 2019, 25, 184-186. [CrossRef] [PubMed]

19. Ge, S.; Li, J.; Fan, X.; Liu, F.; Li, L.; Wang, Q.; Ren, W.; Bao, J.; Liu, C.; Wang, H.; et al. Molecular Characterization of African Swine Fever Virus, China, 2018. Emerg. Infect. Dis. 2018, 24, 2131-2133. [CrossRef]

20. Davies, K.; Goatley, L.C.; Guinat, C.; Netherton, C.L.; Gubbins, S.; Dixon, L.K.; Reis, A.L. Survival of African Swine Fever Virus in Excretions from Pigs Experimentally Infected with the Georgia 2007/1 Isolate. Transbound. Emerg. Dis. 2017, 64, 425-431. [CrossRef]

21. Guinat, C.; Gogin, A.; Blome, S.; Keil, G.; Pollin, R.; Pfeiffer, D.U.; Dixon, L. Transmission routes of African swine fever virus to domestic pigs: Current knowledge and future research directions. Vet. Rec. 2016, 178, 262-267. [CrossRef]

22. Guinat, C.; Gubbins, S.; Vergne, T.; Gonzales, J.L.; Dixon, L.; Pfeiffer, D.U. Experimental pig-to-pig transmission dynamics for African swine fever virus, Georgia 2007/1 strain. Epidemiol. Infect. 2016, 144, 25-34. [CrossRef] [PubMed]

23. Niederwerder, M.C.; Stoian, A.M.M.; Rowland, R.R.R.; Dritz, S.S.; Petrovan, V.; Constance, L.A.; Gebhardt, J.T.; Olcha, M.; Jones, C.K.; Woodworth, J.C.; et al. Infectious Dose of African Swine Fever Virus When Consumed Naturally in Liquid or Feed. Emerg. Infect. Dis. 2019, 25, 891-897. [CrossRef] [PubMed]

24. Chenais, E.; Depner, K.; Guberti, V.; Dietze, K.; Viltrop, A.; Stahl, K. Epidemiological considerations on African swine fever in Europe 2014-2018. Porcine Health Manag. 2019, 5, 6. [CrossRef] [PubMed]

25. Alonso, C.; Borca, M.; Dixon, L.; Revilla, Y.; Rodriguez, F.; Escribano, J.M.; Ictv Report, C. ICTV Virus Taxonomy Profile: Asfarviridae. J. Gen. Virol. 2018, 99, 613-614. [CrossRef] [PubMed]

26. Chapman, D.A.; Tcherepanov, V.; Upton, C.; Dixon, L.K. Comparison of the genome sequences of non-pathogenic and pathogenic African swine fever virus isolates. J. Gen. Virol. 2008, 89, 397-408. [CrossRef] [PubMed]

27. de Villiers, E.P.; Gallardo, C.; Arias, M.; da Silva, M.; Upton, C.; Martin, R.; Bishop, R.P. Phylogenomic analysis of 11 complete African swine fever virus genome sequences. Virology 2010, 400, 128-136. [CrossRef] [PubMed]

28. Dixon, L.K.; Chapman, D.A.; Netherton, C.L.; Upton, C. African swine fever virus replication and genomics. Virus Res. 2013, 173, 3-14. [CrossRef]

29. Alejo, A.; Matamoros, T.; Guerra, M.; Andres, G. A proteomic atlas of the African swine fever virus particle. J. Virol. 2018. [CrossRef]

30. Stone, S.S.; Hess, W.R. Antibody response to inactivated preparations of African swine fever virus in pigs. Am. J. Vet. Res. 1967, 28, 475-481.

31. Blome, S.; Gabriel, C.; Beer, M. Modern adjuvants do not enhance the efficacy of an inactivated African swine fever virus vaccine preparation. Vaccine 2014, 32, 3879-3882. [CrossRef]

32. King, K.; Chapman, D.; Argilaguet, J.M.; Fishbourne, E.; Hutet, E.; Cariolet, R.; Hutchings, G.; Oura, C.A.; Netherton, C.L.; Moffat, K.; et al. Protection of European domestic pigs from virulent African isolates of African swine fever virus by experimental immunisation. Vaccine 2011, 29, 4593-4600. [CrossRef]

33. Gallardo, C.; Sanchez, E.G.; Perez-Nunez, D.; Nogal, M.; de Leon, P.; Carrascosa, A.L.; Nieto, R.; Soler, A.; Arias, M.L.; Revilla, Y. African swine fever virus (ASFV) protection mediated by NH/P68 and NH/P68 recombinant live-attenuated viruses. Vaccine 2018. [CrossRef] [PubMed] 
34. O'Donnell, V.; Holinka, L.G.; Gladue, D.P.; Sanford, B.; Krug, P.W.; Lu, X.; Arzt, J.; Reese, B.; Carrillo, C.; Risatti, G.R.; et al. African Swine Fever Virus Georgia Isolate Harboring Deletions of MGF360 and MGF505 Genes Is Attenuated in Swine and Confers Protection against Challenge with Virulent Parental Virus. J. Virol. 2015, 89, 6048-6056. [CrossRef]

35. O’Donnell, V.; Holinka, L.G.; Krug, P.W.; Gladue, D.P.; Carlson, J.; Sanford, B.; Alfano, M.; Kramer, E.; Lu, Z.; Arzt, J.; et al. African Swine Fever Virus Georgia 2007 with a Deletion of Virulence-Associated Gene 9GL (B119L), when Administered at Low Doses, Leads to Virus Attenuation in Swine and Induces an Effective Protection against Homologous Challenge. J. Virol. 2015, 89, 8556-8566. [CrossRef] [PubMed]

36. O'Donnell, V.; Risatti, G.R.; Holinka, L.G.; Krug, P.W.; Carlson, J.; Velazquez-Salinas, L.; Azzinaro, P.A.; Gladue, D.P.; Borca, M.V. Simultaneous Deletion of the 9GL and UK Genes from the African Swine Fever Virus Georgia 2007 Isolate Offers Increased Safety and Protection against Homologous Challenge. J. Virol. 2017, 91. [CrossRef]

37. Monteagudo, P.L.; Lacasta, A.; Lopez, E.; Bosch, L.; Collado, J.; Pina-Pedrero, S.; Correa-Fiz, F.; Accensi, F.; Navas, M.J.; Vidal, E.; et al. BA71DeltaCD2: A New Recombinant Live Attenuated African Swine Fever Virus with Cross-Protective Capabilities. J. Virol. 2017, 91. [CrossRef] [PubMed]

38. Reis, A.L.; Abrams, C.C.; Goatley, L.C.; Netherton, C.; Chapman, D.G.; Sanchez-Cordon, P.; Dixon, L.K. Deletion of African swine fever virus interferon inhibitors from the genome of a virulent isolate reduces virulence in domestic pigs and induces a protective response. Vaccine 2016, 34, 4698-4705. [CrossRef]

39. Reis, A.L.; Goatley, L.C.; Jabbar, T.; Sanchez-Cordon, P.J.; Netherton, C.L.; Chapman, D.A.G.; Dixon, L.K. Deletion of the African Swine Fever Virus Gene DP148R Does Not Reduce Virus Replication in Culture but Reduces Virus Virulence in Pigs and Induces High Levels of Protection against Challenge. J. Virol. 2017, 91. [CrossRef] [PubMed]

40. Leitao, A.; Cartaxeiro, C.; Coelho, R.; Cruz, B.; Parkhouse, R.M.; Portugal, F.; Vigario, J.D.; Martins, C.L. The non-haemadsorbing African swine fever virus isolate ASFV/NH/P68 provides a model for defining the protective anti-virus immune response. J. Gen. Virol. 2001, 82, 513-523. [CrossRef]

41. Reis, A.L.; Parkhouse, R.M.; Penedos, A.R.; Martins, C.; Leitao, A. Systematic analysis of longitudinal serological responses of pigs infected experimentally with African swine fever virus. J. Gen. Virol. 2007, 88, 2426-2434. [CrossRef]

42. Mulumba-Mfumu, L.K.; Goatley, L.C.; Saegerman, C.; Takamatsu, H.H.; Dixon, L.K. Immunization of African Indigenous Pigs with Attenuated Genotype I African Swine Fever Virus OURT88/3 Induces Protection Against Challenge with Virulent Strains of Genotype, I. Transbound. Emerg. Dis. 2015. [CrossRef] [PubMed]

43. Abrams, C.C.; Goatley, L.; Fishbourne, E.; Chapman, D.; Cooke, L.; Oura, C.A.; Netherton, C.L.; Takamatsu, H.H.; Dixon, L.K. Deletion of virulence associated genes from attenuated African swine fever virus isolate OUR T88/3 decreases its ability to protect against challenge with virulent virus. Virology 2013, 443, 99-105. [CrossRef] [PubMed]

44. Ruiz-Gonzalvo, F.; Rodriguez, F.; Escribano, J.M. Functional and immunological properties of the baculovirus-expressed hemagglutinin of African swine fever virus. Virology 1996, 218, 285-289. [CrossRef] [PubMed]

45. Ruiz-Gonzalvo, F.; Coll, J.M. Characterization of a soluble hemagglutinin induced in African swine fever virus-infected cells. Virology 1993, 196, 769-777. [CrossRef]

46. Gomez-Puertas, P.; Rodriguez, F.; Oviedo, J.M.; Brun, A.; Alonso, C.; Escribano, J.M. The African swine fever virus proteins p54 and p30 are involved in two distinct steps of virus attachment and both contribute to the antibody-mediated protective immune response. Virology 1998, 243, 461-471. [CrossRef] [PubMed]

47. Barderas, M.G.; Rodriguez, F.; Gomez-Puertas, P.; Aviles, M.; Beitia, F.; Alonso, C.; Escribano, J.M. Antigenic and immunogenic properties of a chimera of two immunodominant African swine fever virus proteins. Arch. Virol. 2001, 146, 1681-1691. [CrossRef] [PubMed]

48. Neilan, J.G.; Zsak, L.; Lu, Z.; Burrage, T.G.; Kutish, G.F.; Rock, D.L. Neutralizing antibodies to African swine fever virus proteins p30, p54, and p72 are not sufficient for antibody-mediated protection. Virology 2004, 319, 337-342. [CrossRef]

49. Lopera-Madrid, J.; Osorio, J.E.; He, Y.; Xiang, Z.; Adams, L.G.; Laughlin, R.C.; Mwangi, W.; Subramanya, S.; Neilan, J.; Brake, D.; et al. Safety and immunogenicity of mammalian cell derived and Modified Vaccinia Ankara vectored African swine fever subunit antigens in swine. Vet. Immunol. Immunopathol. 2017, 185, 20-33. [CrossRef] 
50. Oura, C.A.; Denyer, M.S.; Takamatsu, H.; Parkhouse, R.M. In vivo depletion of CD8+ T lymphocytes abrogates protective immunity to African swine fever virus. J. Gen. Virol. 2005, 86, 2445-2450. [CrossRef]

51. Argilaguet, J.M.; Perez-Martin, E.; Nofrarias, M.; Gallardo, C.; Accensi, F.; Lacasta, A.; Mora, M.; Ballester, M.; Galindo-Cardiel, I.; Lopez-Soria, S.; et al. DNA vaccination partially protects against African swine fever virus lethal challenge in the absence of antibodies. PLOS ONE 2012, 7, e40942. [CrossRef]

52. Argilaguet, J.M.; Perez-Martin, E.; Gallardo, C.; Salguero, F.J.; Borrego, B.; Lacasta, A.; Accensi, F.; Diaz, I.; Nofrarias, M.; Pujols, J.; et al. Enhancing DNA immunization by targeting ASFV antigens to SLA-II bearing cells. Vaccine 2011, 29, 5379-5385. [CrossRef] [PubMed]

53. Lacasta, A.; Ballester, M.; Monteagudo, P.L.; Rodriguez, J.M.; Salas, M.L.; Accensi, F.; Pina-Pedrero, S.; Bensaid, A.; Argilaguet, J.; Lopez-Soria, S.; et al. Expression library immunization can confer protection against lethal challenge with African swine fever virus. J. Virol. 2014, 88, 13322-13332. [CrossRef] [PubMed]

54. Argilaguet, J.M.; Perez-Martin, E.; Lopez, S.; Goethe, M.; Escribano, J.M.; Giesow, K.; Keil, G.M.; Rodriguez, F. BacMam immunization partially protects pigs against sublethal challenge with African swine fever virus. Antiviral Res. 2013, 98, 61-65. [CrossRef] [PubMed]

55. Murgia, M.V.; Mogler, M.; Certoma, A.; Green, D.; Monaghan, P.; Williams, D.T.; Rowland, R.R.R.; Gaudreault, N.N. Evaluation of an African swine fever (ASF) vaccine strategy incorporating priming with an alphavirus-expressed antigen followed by boosting with attenuated ASF virus. Arch Virol. 2018. [CrossRef] [PubMed]

56. Lokhandwala, S.; Waghela, S.D.; Bray, J.; Martin, C.L.; Sangewar, N.; Charendoff, C.; Shetti, R.; Ashley, C.; Chen, C.H.; Berghman, L.R.; et al. Induction of Robust Immune Responses in Swine by Using a Cocktail of Adenovirus-Vectored African Swine Fever Virus Antigens. Clin. Vaccine Immunol. 2016, 23, 888-900. [CrossRef]

57. Lokhandwala, S.; Waghela, S.D.; Bray, J.; Sangewar, N.; Charendoff, C.; Martin, C.L.; Hassan, W.S.; Koynarski, T.; Gabbert, L.; Burrage, T.G.; et al. Adenovirus-vectored novel African Swine Fever Virus antigens elicit robust immune responses in swine. PLoS ONE 2017, 12, e0177007. [CrossRef]

58. Chen, X.; Yang, J.; Ji, Y.; Okoth, E.; Liu, B.; Li, X.; Yin, H.; Zhu, Q. Recombinant Newcastle disease virus expressing African swine fever virus protein 72 is safe and immunogenic in mice. Virol. Sin. 2016, 31, 150-159. [CrossRef]

59. Perez-Nunez, D.; Sunwoo, S.Y.; Sanchez, E.G.; Haley, N.; Garcia-Belmonte, R.; Nogal, M.; Morozov, I.; Madden, D.; Gaudreault, N.N.; Mur, L.; et al. Evaluation of a viral DNA-protein immunization strategy against African swine fever in domestic pigs. Vet. Immunol. Immunopathol. 2019, 208, 34-43. [CrossRef]

60. Sunwoo, S.Y.; Perez-Nunez, D.; Morozov, I.; Sanchez, E.G.; Gaudreault, N.N.; Trujillo, J.D.; Mur, L.; Nogal, M.; Madden, D.; Urbaniak, K.; et al. DNA-Protein Vaccination Strategy Does Not Protect from Challenge with African Swine Fever Virus Armenia 2007 Strain. Vaccines 2019, 7, 12. [CrossRef]

61. Jancovich, J.K.; Chapman, D.; Hansen, D.T.; Robida, M.D.; Loskutov, A.; Craciunescu, F.; Borovkov, A.; Kibler, K.; Goatley, L.; King, K.; et al. Immunization of Pigs by DNA Prime and Recombinant Vaccinia Virus Boost To Identify and Rank African Swine Fever Virus Immunogenic and Protective Proteins. J. Virol. 2018, 92. [CrossRef]

62. Escribano, J.M.; Galindo, I.; Alonso, C. Antibody-mediated neutralization of African swine fever virus: Myths and facts. Virus Res. 2013, 173, 101-109. [CrossRef] [PubMed]

63. Kollnberger, S.D.; Gutierrez-Castaneda, B.; Foster-Cuevas, M.; Corteyn, A.; Parkhouse, R.M. Identification of the principal serological immunodeterminants of African swine fever virus by screening a virus cDNA library with antibody. J. Gen. Virol. 2002, 83, 1331-1342. [CrossRef] [PubMed]

64. Gallardo, C.; Reis, A.L.; Kalema-Zikusoka, G.; Malta, J.; Soler, A.; Blanco, E.; Parkhouse, R.M.; Leitao, A. Recombinant antigen targets for serodiagnosis of African swine fever. Clin. Vaccine Immunol. 2009, 16, 1012-1020. [CrossRef] [PubMed]

65. Zsak, L.; Onisk, D.V.; Afonso, C.L.; Rock, D.L. Virulent African swine fever virus isolates are neutralized by swine immune serum and by monoclonal antibodies recognizing a 72-kDa viral protein. Virology 1993, 196, 596-602. [CrossRef] [PubMed]

66. Borca, M.V.; Irusta, P.; Carrillo, C.; Afonso, C.L.; Burrage, T.; Rock, D.L. African swine fever virus structural protein p72 contains a conformational neutralizing epitope. Virology 1994, 201, 413-418. [CrossRef] [PubMed] 
67. Gomez-Puertas, P.; Rodriguez, F.; Oviedo, J.M.; Ramiro-Ibanez, F.; Ruiz-Gonzalvo, F.; Alonso, C.; Escribano, J.M. Neutralizing antibodies to different proteins of African swine fever virus inhibit both virus attachment and internalization. J. Virol. 1996, 70, 5689-5694. [PubMed]

68. Pan, I.C.; De Boer, C.J.; Heuschele, W.P. Hypergammaglobulinemia in swine infected with African swine fever virus. Proc. Soc. Exp. Biol. Med. 1970, 134, 367-371. [CrossRef]

69. Ramiro-Ibanez, F.; Ortega, A.; Ruiz-Gonzalvo, F.; Escribano, J.M.; Alonso, C. Modulation of immune cell populations and activation markers in the pathogenesis of African swine fever virus infection. Virus Res. 1997, 47, 31-40. [CrossRef]

70. Halstead, S.B.; Mahalingam, S.; Marovich, M.A.; Ubol, S.; Mosser, D.M. Intrinsic antibody-dependent enhancement of microbial infection in macrophages: Disease regulation by immune complexes. Lancet Infect. Dis. 2010, 10, 712-722. [CrossRef]

71. Taylor, A.; Foo, S.S.; Bruzzone, R.; Dinh, L.V.; King, N.J.; Mahalingam, S. Fc receptors in antibody-dependent enhancement of viral infections. Immunol. Rev. 2015, 268, 340-364. [CrossRef]

72. Yoon, K.J.; Wu, L.L.; Zimmerman, J.J.; Hill, H.T.; Platt, K.B. Antibody-dependent enhancement (ADE) of porcine reproductive and respiratory syndrome virus (PRRSV) infection in pigs. Viral Immunol. 1996, 9 , 51-63. [CrossRef] [PubMed]

73. Halstead, S.B.; Chow, J.S.; Marchette, N.J. Immunological enhancement of dengue virus replication. Nat. New Biol. 1973, 243, 24-26. [PubMed]

(C) 2019 by the authors. Licensee MDPI, Basel, Switzerland. This article is an open access article distributed under the terms and conditions of the Creative Commons Attribution (CC BY) license (http://creativecommons.org/licenses/by/4.0/). 